\title{
Business Leaders as Citizens of the World. Advancing Humanism on a Global Scale
}

\begin{abstract}
As the world is getting increasingly connected and interdependent it becomes clear that the world's most pressing public problems such as poverty or global warming call for cross-sector solutions. The paper discusses the idea of business leaders acting as agents of world benefit, taking an active co-responsibility in generating solutions to problems. It argues that we need responsible global leaders who are aware of the pressing problems in the world, care for the needs of others, aspire to make this world a better place, and act in word and deed as global and responsible citizens. The argument is structured as follows: first, in highlighting some leadership challenges we discuss why it takes a responsible, global, and ultimately cosmopolitan mindset to enhance human values on a global scale. Second, we define more specifically responsible global leadership and the (potential) role
\end{abstract}

Thomas Maak is Research Director at the University of St. Gallen in Switzerland, Visiting Senior Research Fellow at INSEAD, France, and Visiting Professor at ESADE Business School, Barcelona, Spain. He received his PhD, summa cum laude, from the University of St. Gallen. He held visiting positions at Columbia University, New York and at Georgetown University in Washington, DC. His research and teaching focuses on business ethics, corporate citizenship, integrity management, HRM, and responsible leadership. Dr. Maak is also is a member of the Executive Committees of the European Business Ethics Network (EBEN) and the International Society for Business, Ethics and Economics (ISBEE).

Nicola M. Pless is Associate Professor at ESADE Business School, Barcelona, Spain and Visiting Senior Research Fellow at INSEAD, France. She received MSc degree from the University of Bayreuth, PhD degree in organizational theory from the University of St. Gallen, and a diploma in clinical organizational psychology from INSEAD. Prior to her academic career she worked as a Vice President in the financial services industry and served at the World Bank Group in Washington, DC. Her research, writing and teaching focuses on international management, responsible leadership, and leadership development. of business leaders acting as agents of world benefit. Third, drawing on latest research on cosmopolitanism, we discuss the hallmarks of contemporary cosmopolitanism. Fourth, and concluding our argument, we propose key cosmopolitan business principles to help leaders build a more inclusive world.

KEY WORDS: cosmopolitanism, social justice, global business ethics, responsible leadership

There is growing awareness that some of the world's most pressing problems - such as poverty, access to clean drinking water, HIV/AIDS, and global warming - require cross-sectoral efforts and solutions. Neither governments nor communities, nor NGOs, nor businesses, can solve these problems alone. Spanning sectors and bridging boundaries, however, is not an easy task. Multiple interests and values need to be balanced. As the world is getting increasingly connected and interdependent, or "flat" (Friedman, 2005), it is also getting more complex (Hooijberg et al., 1997). In fact, since public, private, and non-profit sectors have always played interlocking roles in global problem solving, their distinctive roles need to be adapted to the realities of global markets in the twenty-first century, each sector contributing by way of exercising a distinctive role in the "complex ballet of interwoven actions" (Sachs, 2008) to tackle some of the world's most pressing problems and to help build a sustainable future.

According to widely cited UNCTAD data, of the 100 largest economies in the world, 51 are now global corporations, only 49 are countries. As global power relations are shifting stakeholders and communities around the world are no longer satisfied that corporations and their leaders are merely law-abiding as 
they go about increasing shareholder value (Lodge and Wilson, 2006). Instead, they expect awareness of and commitment to the needs of communities and thus acknowledgement of a co-responsibility vis-àvis the above-mentioned problems (Maak, 2007). In fact, there is widespread agreement not only in societies, but also in the business world that multinational corporations and their leaders in particular have the means and thus the power to act as agents of world benefit (see, e.g., BAWB, 2006) in tackling pressing public problems. At the same time, however, many stakeholders still do not trust corporations and business leaders to provide "more" because they have not in the past (Lodge and Wilson, 2006). In other words, business leaders are facing both growing expectations to do "more" and a lack of trust in their intentions to do good and do things right. Still, recent developments and initiatives such as the multi-stakeholder forum UN Global Compact, the Global Business Coalition on HIV/AIDS, the Business Leaders Initiative on Human Rights (BLIHR), the World Business Council for Sustainable Development (WBCSD) "Tomorrow's Leaders Group", or the European Foundation of Management Development's (EFMD) "Call for Responsible Global Leadership" are clear indicators that multinational corporations and their leaders are beginning to answer the call for a more active role in contributing to solving some of the world's most pressing problems. There is growing awareness as to what corporations and their leaders ought to do in the years to come: "each company needs to be part of the solution and needs to stretch its activities beyond normal market activities. This does not mean to turn the company upside down or into a charitable institution, but rather to identify the unique contribution the company may make as part of a broader effort to solve a major social challenge" (Sachs, 2008).

We posit that in light of both rising expectations and declining legitimacy this endeavor ultimately requires responsible global business leaders (Maak, 2007; Maak and Pless, 2006) - leaders who think and act as cosmopolitan citizens. Cosmopolitan business leaders are aware of the pressing problems in the world, care for the needs of others, and in particular for the distant needy, aspire to make this world a better place and act in word and deed as global and responsible citizens. In short, they demonstrate both cosmopolitan mindset and attitude. Levy et al. (2007) have analyzed the growing body in management literature on the global mindset and found that cosmopolitanism "should be viewed as one of the major conceptual dimensions" (p. 239), although it seems to be an underlying, more implicit theme rather than an explicit dimension. It is our intention in what follows to flesh out cosmopolitanism as it applies to global business leadership in more explicit terms.

If this world is to be a decent world in the future, Martha Nussbaum contends, "we must acknowledge right now that we are citizens of one interdependent world, held together by mutual fellowship as well as the pursuit of mutual advantage, by compassion as well as self-interest, by a love of human dignity in all people, even when there is nothing we have to gain from cooperating with them" (2005, p. 217). Thus, the cosmopolitan project is ultimately about creating a decent world; a fair, inclusive, just and thus principle-driven global community that enables human flourishing and seeks to build human capabilities. The "right now" in Nussbaum's quote signals a sense of urgency. We share Nussbaum's concern and seek to further the cosmopolitan project by illuminating the role of business leaders in contributing to global fairness and social justice and thus in making this world a better, i.e., more humane place.

\section{Responsible leadership in a global stakeholder society}

The stakeholder framework has certainly proved useful in the analysis of strategic and normative challenges organizations face, and good stakeholder relationships are arguably key to organizational viability (Donaldson and Preston, 1995; Freeman, 1984, 1994; Post et al., 2002; Wheeler and Sillanpäa, 1997). Yet, business leaders are faced with multiple stakeholder claims, based on different and, more often than not, conflicting values. Thus, there are challenges with respect to stakeholder salience (Jones et al., 2007; Mitchell et al., 1997) and with respect to evaluating and balancing the claims of multiple stakeholders such as employees, clients, shareholder, suppliers, or NGOs, both inside and outside an organization. Responsible leadership requires assessing and weighing the impact of 
organizational behavior on all relevant stakeholders (Pless and Maak, 2005) and the engaging in multiple relationships beyond the leader's hierarchical domain. In other words, in a stakeholder society it becomes a key challenge for a leader to enable inclusive stakeholder engagement and dialogue to help balance diverse claims and ensure ethically sound decision making. In fact, it could be argued that leaders face the challenge of weaving a web of sustainable relationships (Maak and Pless, 2006b) to a multitude of stakeholders, most of which are located outside the hierarchical leadership dyad, to create trust and ultimately stakeholder social capital (Maak, 2007).

Moreover, balancing stakeholder claims on a global level, including those of the natural environment, future generations and less privileged groups "at the bottom of the pyramid" (Prahalad, 2005) creates new social and humanitarian challenges. While many corporations have adopted a "triplebottom-line" approach (Elkington, 1998), integrating social and environmental considerations into their value creations, few have yet taken on humanitarian challenges - poverty, hunger, diseases, and injustice - which still prevent large parts of the human community from participating in the global economy, let alone benefiting from it. The actual leadership challenge at hand is therefore not only to live up to legitimate stakeholder expectations, but also to actively engage in novel ways of doing business in less privileged regions of the world by building and supporting human capabilities (Nussbaum and Sen, 1993) and by assisting in eradicating world poverty. Whether or not there is a "fortune at the bottom of pyramid" (Prahalad, 2005) remains to be seen and is largely beside the point; fact is that multinational corporations (MNCs) in particular "are being exhorted to pursue a broader range of human development objectives as part of their core business operations. The task is therefore for MNC leaders to organize a legitimate way to achieve those desirable results while at the same time retaining commercial viability" (Lodge and Wilson, 2006, p. 154). Thus, according to Lodge and Wilson farsighted leaders "have recognized that the source of their legitimacy has moved, and that alongside shareholder satisfaction (...) has come the servicing of community needs, however they might be defined" (2006, p. 40).
As a consequence, business legitimacy increasingly depends on how an organization delivers on human rights, alleviating poverty, and global sustainability. And while MNCs, given their scope, outreach, and global activities are still a major focus of attention, "rapidly increasing global interconnectedness" (Adler, 2006, p. 488) and interdependence, and thus the "flattening" of the economic world as we knew it (Friedman, 2005), require from leaders in corporations both global and local, large and small, to deliver on the above-mentioned problems.

Still, does this imply that nowadays business leaders are responsible for solving all pressing public problems in the world? To be clear, we are not arguing here that business leaders are responsible for, or should be held accountable for, solving all the world's ills. Their primary concern is, and ought to be, to run a profitable business that creates "shared value" (Porter and Kramer, 2006) for all of its stakeholders. Yet, as we sketched out in the beginning there is despite scepticism vis-à-vis the role and responsibilities of business leaders a growing shift in expectation as to what global corporations and their leadership should contribute to solving pressing public issues. At the same time there is recognition and increasingly also a willingness among business leaders to engage in this task. In summary, then, we argue that given the power, potential, and abilities of business leaders to make this world a better place the least we can expect from business leaders is that they recognize their co-responsibility for addressing some of the world's most pressing problems; not as one-dimensional agents of shareholder interests, but as active and reflective citizens of the world who happen to be managers and leaders in a corporation.

Against this backdrop we define responsible leadership as a values-based and principle-driven relationship between leaders and stakeholders who are connected through a shared sense of meaning and purpose through which they raise to higher levels of motivation and commitment for achieving sustainable value creation and responsible change (Maak and Pless, 2006b; Pless, 2007). Thus, to qualify as responsible leadership needs to be driven by ethical principles (Ciulla, 1998) and values that enable both leader and followers to find a common meaning and purpose, such as contributing to a sustainable future or assisting the distant needy. Moreover, 
leadership occurs in interaction between leaders and followers. As obvious as this may sound, in a stakeholder society followers are not necessarily subordinates but can also be other internal or external constituencies (Freeman et al., 2006; Maak and Pless, 2006b, p. 106), who have a stake in the leadership project. Yet, broadening the view from a leader-subordinate relationship to a leader-stakeholder relationship challenges some of the basic assumptions in traditional leadership theory which to date understands the leader-follower relationship as an unequal relationship with the leader being in charge (Bennis and Nanus, 1985) and followers being dedicated to "do the leader's wishes" (Rost, 1991, p. 70). In contrast, responsible leadership in a stakeholder environment calls for leaders who are able to mobilize others as collaborators (Maccoby, 2007) in the pursuit of contributing to the common good, for in this environment stakeholders tend to join, not follow, the leader (Schneider, 2002, p. 218).

And finally, since the leadership relationship ought to be driven by a commonly shared purpose (Rost, 1991) leader and stakeholder raise one another on "level playing field" in dynamic ways "to higher levels of motivation and morality" (Burns, 1978, p. 20). Thus, inherent in this definition and connected to the idea of a sustainable future is also the normative aspiration for "transforming leadership" (Burns, 1978) by way of achieving responsible change for the betterment of this world. In this sense, business leaders have the potential to contribute to solutions for problems and to fostering sustainable development on a global scale - as "agents of world benefit" (BAWB, 2006).

Still, even if we agree that business leaders ought to contribute in more active and explicit ways to the cosmopolitan agenda can we, or should we even, hold business leaders responsible for addressing global public problems? Even if we find the abovementioned stakeholder expectations to be reasonable, are business leaders, firstly, really responsible for addressing pressing social problems and secondly, should business leaders even engage as agents of social justice? Do we, as fellow citizens of the world, want business leaders to act as "quasi-governments"? In addressing these questions we seek to shed more light on both the actual responsibility and legitimacy of business leaders acting as citizens of the world.

\section{Business leaders as agents of world benefit?}

Are business leaders responsible for solving the world's most pressing problems?

In a more recent contribution on "responsibility and global labor justice" (2004) regarding the problem of so-called sweatshops the late Iris Young presented the argument that business leaders in faraway boardrooms bear indeed some responsibility for what happens in manufacturing operations in developing countries. She stressed however that this responsibility is different, or in fact has to be different from the mere legal responsibility of local factory owners and managers (2004, p. 375). While these are responsible for what happens in their factories in the sense of liability - and may be blamed afterward for what has happened - business leaders in well-off places usually cannot be held liable; thus, their responsibility has to be different and is indeed, as Young argues. Business leaders are responsible for harmful or unjust conditions in a political sense. Just like any other participant in the global economy, if in a much more active role, business leaders bear a political responsibility for what happens, or does not happen, at the remote outposts of our global economy. In fact, "(w)hereas responsibility as liability assigns responsibility according to what particular agents have done, on the model of political responsibility individuals are responsible precisely for things they themselves have not done" (Young, 2004 , p. 375 , emphasis). To pick an example, while a corporation-like Nike might not be held liable for, say, the miserable working conditions in sub-contracted outposts of their supply-chain in China, it still bears a political responsibility for not making sure that each and every supplier adheres to the same basic standards of production.

We believe that Young is right in her reasoning and thus in defining and assigning, a specific political responsibility to all actors in the global economy. "Political" connotes activities broader than a government's, namely those "in which people organize collectively to regulate or transform some aspect of their shared social conditions, along with the communicative activities in which they try to persuade one another to join such collective action or decide what direction they wish to take it" (Young, 2004, p. 377). Building on this line of reasoning it can be 
argued that although business leaders or the firms they lead have not caused poverty, at least not directly, as members of the global political community they still bear some political responsibility for what they have not done, or caused; that is, e.g., the socio-economic conditions in developing countries. Obviously, this applies to miserable working conditions and other tangible miseries as it does to the global market framework, i.e., the conditions and the design of the global economic order (Pogge, 2002). However, it also applies to the world's most pressing public problems such as severe poverty (and hunger), access to clean drinking water and diseases like HIV/AIDS and malaria.

The political responsibility in addressing these problems is therefore a "shared responsibility" (May, 1993) among citizens of the world. Yet, because of their specific position in the network of social and economic structures (Maak, 2007) in our interconnected world business leaders bear more responsibility than others. This position may be described by three main characteristics: power, privilege, and potential.

\section{Power}

Clearly, most business leaders, given their position in structural processes in the global economy, carry substantial degrees of actual or potential power over these processes and their outcomes. They can influence, for better or for worse, the degree to which corporations do good in and beyond the immediate confines of their organization. Moreover, groups of leaders in network organizations such as the World Business Council for Sustainable Development or the Business Leaders Initiative on Human Rights (BLIHR) have concerted power to impact the global market framework for the benefit of the many, and in particular the poor and distant needy. In addition, business leaders also have the power not to invest or do business that is, to withhold their engagement. Beck (2008, p. 796) therefore argues that inherent to globalization as we know it today is thus the precise opposite of the classic theory of power: "the threat is no longer of an invasion but of the non-invasion (or withdrawal) of investors. Thus, in addition to the individual power of each business leader and the collective power of leaders to engage in concerted efforts for the global common good there is also the reverse power not to engage oneself or one's company in hitherto neglected locations around the world. In the end, then, given the various degrees of power to make this world a better, i.e., more inclusive, place to live and work (or not) we find enough substance to support the argument that business leaders are well-advised to engage more actively in the fight against the world's most pressing problems.

\section{Privilege}

According to UN estimates roughly one half of the world's population live in conditions of severe poverty. The other half, most of whom are living in a developed country and stable democracy, are by comparison relatively well-off and therefore privileged. Young (2004, p. 387) argues that such privilege generates special responsibilities, in particular with respect to improving people's livelihoods in the least developed regions of the world. Business leaders, given their position to influence the structures of income generation and wealth creation, their sometimes substantial personal resources and access to organizational resources, are even more privileged and thus by virtue of their position bear a responsibility to act as an agent of world benefit. Yet, all of us living in developed countries and thus relatively well-off places should be concerned about our fellow citizens in the world, in particular the distant needy. This involved cosmopolitan attitudes and having an expansive view of moral concern for less-privileged, others on the basis of our shared humanity (Driver, 2007, p. 595).

\section{Potential}

Moreover, given their access to means, both material and immaterial, and their potential ability to mobilize people to engage in responsible change activities to assist others in need; and given their position in a network of stakeholder relations, business leaders possess a unique potential to mobilize others, i.e., internal and external stakeholders, to do good. By being embedded in a relational network business leaders have access to social network structures in ways that people in non-leadership positions usually 
do not have. In fact, Maak (2007) argues that a responsible leader acts as a weaver of stakeholder relationships and as a broker of social capital in the pursuit of responsible change. Responsible leadership, then, may result in the creation of value networks (Lord and Brown, 2001, p. 141) of multiple stakeholders, which enhance social capital and thereby contribute to both a sustainable business and the common good. Put differently, business leaders in positions of influence possess a unique potential to do good.

What we find in conclusion is that business leaders do indeed have a specific political responsibility with respect to solving some of the world's most pressing problems. Given their power to make this world a better place, their being in a privileged position and their potential in providing the means and in facilitating responsible change, we as fellow citizens of the world may reasonably expect that business leaders act (at least to some extent) as agents of world benefit (rather than world misery).

\section{Should business leaders act as agents of social justice?}

While there is growing agreement among stakeholders that businesses and their leaders ought to do "more" and engage in active ways in tackling pressing public problems, especially in the least developed regions of the world, there is much less consensus on corporations acting as active proponents of human rights and agents of social justice. Should businesses and their leaders actively engage in promoting human rights and thus become in such instances active political actors?

The scepticism vis-à-vis private, interest-driven actors engaging in a political role is caused by the common perception that states are the "primary agents of justice" (O'Neill, 2004) and therefore are "ontologically privileged" (Held, 2005, p. 10) in the delivery of liberty and justice. However, as David Held points out, while "states are hugely important vehicles" to aid the delivery of justice, contemporary cosmopolitanism - to which we turn in the following section - must go further, "and build an ethically sound and politically robust conception of the proper basis of political community..." (Held, 2005 , p. 10). Such community includes corporate citizens; in fact in less developed regions of the world, where states are weak or failing, political progress may depend on corporate actors taking on an active role in building capabilities and promoting justice.

Consequently, O’Neill (2004, p. 246ff.) discusses the following reasons why states should not be considered the sole agents of justice: there are states in developing regions that are simply unjust; moreover, there are "weak states and failing states", unable (or unwilling) to secure the rights of their inhabitants; and finally, globalization has led to weaker nation states, "allowing powerful agents and agencies of other sorts to become more active within their borders." She posits therefore that multinational corporations in some instances cannot simply see themselves as secondary agents of justice; on the contrary, in case of unjust or weak states they need to shoulder active duties in carrying some of the obligations of international justice, e.g., by actively promoting human rights or by instituting social and economic policies.

Obviously, such a contribution may well pose a complex challenge. Most corporations and their leaders lack the political expertise and are thus illequipped to serve as "Ersatz"-governments. Moreover, those who believe that corporations cannot be trusted, may also fear that their actions distort democratic processes rather than help build a system of justice. Yet, in developed democracies with wellestablished political systems, democratic traditions and significant levels of well-being, active civil societies need to and will watch closely how corporations engage as political actors and thereby prevent corporate engagement from undermining these achievements. In cases, however, where states according to O'Neill cannot be considered the primary agents of justice because they are weak, fail, or are even unjust, corporations often provide essential socio-economic infrastructure and may even be "havens" of human and social rights. Thus, in the case of unjust or so-called "rogue" stated that, as Lodge and Wilson (2006) argued, corporations in some ways become governments, i.e., if they refrain from acting like "rogue corporations" (O'Neill, 2005, p. 49) by pursuing mere self-interest without consideration of social or human rights conditions.

In conclusion, since businesses and their leaders are as much part of the global economy as they are 
part of the global political community, and given their ability to exercise active agency and since they have the capabilities to act as agents and thus proponents of justice in the countries in which they operate (O'Neill, 2005, p. 49), they bear - as cosmopolitan citizens - a shared responsibility in promoting human and social rights. Promoting the cosmopolitan agenda and human rights in particular calls for a "moral division of labor" (Nagel, 1991) among cosmopolitan agents. "Distributing responsibilities" (Miller, 2005) to corporations and their leaders as well as to other cosmopolitan actors to deliver on human rights is not so much a vague possibility, but a necessity in a "shared-power world" (Crosby and Bryson, 2005). A responsible leader's choice is therefore to support and promote the areas of justice, in which she is able to contribute. This does not mean that each leader is required to pursue an active political agenda; rather that she actively pursues her political co-responsibility as a leader of a cosmopolitan corporation. Being part of the global community - and a "global political praxis" (Dallmayr, 2003, p. 422, emphasis) means being part of a common moral universe and that allegiance is owed, first and foremost, to the universe of reasoning citizens of equal worth and dignity, not to shareholders.

\section{Cosmopolitanism: revitalizing humanism on a global scale}

In the sections above we addressed both the desirability and the legitimacy of business leaders engaging as agents for world benefit. In what follows we will discuss what it takes to act as an agent for world benefit, that is, mindset and principles. As indicated in the beginning, we posit that such agency requires responsible global business leaders - leaders who think and act as cosmopolitan citizens. Yet, what does it mean to think and act as a cosmopolitan citizen? Are we not all cosmopolitans, citizens of the world?

There is widespread agreement that cosmopolitanism goes back to the Stoics in ancient Greece; Diogenes is to have said, when asked which city he belonged to: "I am a citizen of the world." Boldly stating to be a citizen of both the world (cosmos) and the political community (polis) reflected a rejection of the communitarian confines of the Greek city republics. In the eighteenth century, Kant (1795) imagined a cosmopolitan right ("Weltbürgerrecht") that ought to govern the global relations of citizens worldwide; a right that belongs to all human beings as potential participants in a world republic. Kant's pioneering work serves as a key reference for modern cosmopolitanism, as reflected, e.g., by the UN Declaration of Human Rights; but also by the work of Hannah Arendt, according to Seyla Benhabib: "Following Kant, Arendt likewise argues that 'crimes against humanity' are not violations of moral norms alone, but violations of the rights of humanity in our person" (2006, p. 22) and thus need a special treatment on a global scale.

As for modern cosmopolitanism, globalization and resulting interconnectedness and interdependence have triggered an intensified discussion on cosmopolitan promises and perspectives in a connected world, e.g., with respect to multi-cultural citizenship (Kymlicka, 1995), patriotism (Nussbaum, 1996), global governance (Held, 1995), and philosophical world-views (Bohman and Lutz-Bachmann, 1997). More recently we find substantial contributions to the political theory of cosmopolitanism (see, e.g., Appiah, 2006; Benhabib, 2006; Brock and Brighouse, 2005; Cheah, 2006; Vertovec and Cohen, 2002). Against this backdrop cosmopolitanism may be divided into four connected streams (Maak and Pless, 2008): political cosmopolitanism, ethical cosmopolitanism, a cosmopolitan world-view, and cosmopolitan practice. Political cosmopolitanism is concerned with questions of global governance, political agency, and citizenship in a globalized world. Ethical cosmopolitanism captures the discussion on cosmopolitan justice and human rights issues, cosmopolitan duties, and moral principles such as respect and recognition of difference. Diogenes' statement of being a "citizen of the world" symbolizes a specific cosmopolitan mindset or world-view and reminds us that the state of cosmopolitanism also depends on how we think about cosmopolitanism. In fact, as noted above the much discussed "global mindset" (Levy et al., 2007) depends on "the cosmopolitan imagination" (Delanty, 2006). And finally, particular to twenty-first century cosmopolitanism is an emerging cosmopolitan practice to improve the state of our globalized world. All four variations of cosmopolitanism are needed. In fact, all of them are part of what may be termed the "twenty-first 
century cosmopolitan project". In this sense, cosmopolitanism is a project of mediations and integration (Benhabib, 2006, p. 20). It is not about designing the ultimate global ethic; nor is it equivalent to finding a mere modus vivendi among cultures. Rather, in the Kantian tradition, it connotes the emergence of norms, values, and ideas that ought to govern relations among actors in a global civil society (ibid.), which each and every human being as potential participant in a "world republic". Twenty-first century cosmopolitanism seeks to establish a regime of mutual respect and recognition of human rights; and it envisions a fair, just, and inclusive global economic order, conducive to the life of the many (Maak and Pless, 2008).

\section{Business leaders as citizens of the world}

As argued above, business leaders have the power, the means, and the potential to play an important role not only as leading proponents in the world of global markets by helping to establish an ethically sound market framework, but also in the cosmopolitan universe of rights, respect, and mutual recognition by engaging as agents of justice and ultimately for world benefit, in particular where other agents fail. Therefore, cosmopolitanism does not refer simply to a certain global space or phenomenon, nor is it equivalent to being "global". Rather, it resides in social mechanisms and dynamics that can exist at any time and in any place in society where world openness and a concern for our shared humanity has resonance (Delanty, 2006). Obviously, such engagement is based on normative grounds, that is, certain values and principles in line with cosmopolitan ideals.

\section{Cosmopolitan ethos}

The task of defining cosmopolitan ethics deserves a treatment of its own. It is therefore not our goal, nor is this the place, to elaborate in much detail what such a set of ethical principles would entail. Ambitious attempts in defining a "new world ethic" (Küng, 1991) or "global ethic" (Küng and Kuschel, 1995) have been pursued in recent years and much can be taken from these attempts to connote the cosmopolitan moral vision. Rather, we simply aim to make the case for a specific moral vista and guidepost for responsible global leaders in their attempt to act as citizens of the world. Such a moral point of view offers a point of reflection and introspection, of deliberation and moral ambition to act and lead responsibly in a connected world. We suggest that such cosmopolitan business ethos would need to include at least the following elements: sense of global justice, sense of care, and duty of assistance. These elements tie into three streams of literature and are meant to illustrate the cosmopolitan ethos and not to provide an exhaustive account. Thus, we argue here that such a moral point of view is important and what it may comprise given the challenges outlined above. Yet, we do not attempt to define it as opposed to, say, non-cosmopolitan points of view. What can be said is that such a vista directs its concern toward issues of moral and political relevance in light of challenges and requirements concerning our shared humanity.

\section{Sense of global justice}

As noted above, from a cosmopolitan point of view matters of human rights and global justice are indispensable pillars in creating an inclusive world and in designing institutions which are conducive to the life of the many, and in particular the distant needy. Cosmopolitanism is therefore concerned with the implementation of a human rights regime (see, e.g., Beetham, 1998), and with deliberating and defining "who must deliver on human rights?" (Kuper, 2005), and "freedom from poverty as a human right" (Pogge, 2007) and thus the question "who owes what to the very poor?" Addressing these issues and answering such fundamental questions obviously requires an explicit sense of justice from those who engage in moral and political deliberation and thus knowledge and perspective on matters of distributive global justice, on implementing and fighting for a human rights regime, and on dividing shared responsibilities among key actors in bringing cosmopolitan justice to life. Business leaders do not need to be human rights experts but as leading citizens of the world they need to have a distinct sense of global justice to determine in deliberation processes with fellow citizens (e.g., in 
stakeholder dialogue) who owes what to whom on a global scale, what it requires to take a stand in human rights issues, and to determine the moral duties of businesses and their leadership to engage as agents of (social) justice on a global scale.

\section{Sense of care}

Inherent to a cosmopolitan ethos is an explicit sense of care for the basic needs of others. Arguably, the care perspective finds its most elaborate expression in feminist moral theory (Gilligan, 1982; V. Held, 2005; Noddings, 2003). Still, "caring" is neither limited to "feminine" attributes, nor to aspects of mothering. Instead it draws our attention to the fundamental question about what and especially about whom we really care; to borrow a phrase from Frankfurt (1988). Once we ask ourselves this question, then we need to clarify if our caring attitude is restricted to those close to us, or if we care about others as well, e.g., the distant needy.

Appiah (2006) refers to cosmopolitanism as "ethics in a world of strangers". In this sense, the caring attitude of cosmopolitans reaches beyond close relationships also to distant others; that is, to strangers in the cosmopolitan universe who are less privileged and may require our help and support, such as people in the developing regions of the world. Cosmopolitans, then, show empathy toward those in need, based on mutually shared feelings of human flourishing and vulnerability. The concept of empathy still finds its most eloquent treatment in Adam Smith's "Theory of Moral Sentiments" (1759) and requires to "take seriously the value not just of human life [in general] but of particular human lives, which means taking an interest in the practices and beliefs that lend them significance" (Appiah, 2006, p. xv), even in remote places of the cosmopolitan universe. This sense of moral empathy then leads to a caring attitude about other lives inside and outside the organization, at home and abroad. Thus, empathy in a cosmopolitan sense is directed toward strangers rather than our own kin.

Responsible global business leaders are certainly not responsible for solving all the problems in this world. Yet, since most of them are cosmopolitan citizens in potentially powerful and privileged positions, and since their actions impact many people, it can reasonably be expected that they care about more than just the corporation's bottom line, namely about the conditions of freedoms and livelihood of their fellow citizens at home and abroad.

\section{Duty of assistance}

"Peoples have a duty to assist other peoples living under unfavorable conditions that prevent their just or decent political and social regime" (Rawls, 1999, p. 37). John Rawls' eighth principle of global justice that aims at realizing and preserving "just (or decent) institutions, and not simply to increase, much less to maximize indefinitely, the average level of wealth, or the wealth of any society..." (Rawls, 1999, p. 107), has received considerable attention among philosophers and legal thinkers in recent years [see, e.g., the discussions in Pogge (2002) and Chatterjee (2004)]. Rawls recognizes a duty to assist those in need, but he also insists on setting clear targets to create basic decent conditions.

Rawls has been criticized for the "thinness" of his eighth principle, that is, the "duty of assistance" (Nussbaum, 2005; Pogge, 2002). In fact, Pogge contends that $w e$, the more advantaged citizens of the affluent countries, "are actively responsible for most of the life-threatening poverty in the world" (Pogge, 2005, p. 92) and therefore have the moral duty to help and assist people in less favorable conditions, e.g., through a "global resources dividend". Nussbaum (2005, p. 214, et seq.) argues in a similar vein that "prosperous nations have a responsibility to give a substantial portion of their GDP to poorer nations" and that in fact "multinational corporations have responsibilities for promoting human capabilities in the regions in which they operate." While we cannot discuss Rawls' principle or Pogge's and Nussbaum's suggestions in more detail here it is important to note that both stress the cosmopolitan principle of active agency and thus argue for a "thicker" conception (Walzer, 1994) in assisting fellow humans in securing the basic needs to lead a decent life. It is in this sense that we argue that business leaders as cosmopolitan citizens have the moral duty to assist others in much less favorable conditions, and that they bear the responsibility to assure that their organizations act in the spirit of this principle as good corporate citizens around the world. 


\section{Cosmopolitan leadership principles}

In the beginning we defined responsible leadership as a values-based and principle-driven relationship between leaders and stakeholders who are connected through a shared sense of meaning and purpose for achieving sustainable value creation and responsible change. As such it aims at transforming the (business) world for the better. For positive transformation to happen the cosmopolitan ethos needs to become actionable. In what follows we therefore build on Held's (2005) suggestion of eight basic cosmopolitan principles (equal worth and dignity; active agency; personal responsibility and accountability; consent; collective decision making about public matters; inclusiveness and subsidarity; avoidance of serious harm; and sustainability) and adapt and complement these principles for the purpose of suggesting a list of cosmopolitan leadership principles - principles that may help transform the cosmopolitan ethos and guide a cosmopolitan business leader in her endeavor to run a responsible and sustainable business.

It should be noted that these principles are cosmopolitan insofar as they address moral issues of particular cosmopolitan concern. They are different from regular moral principles only in the extent of their global scope and outreach, e.g., to the distant needy in least developed regions of the world, not in their nature: embedded in a cosmopolitan mindset they are an integral part of what constitutes the attitudes of a citizen of the world - reflecting an explicit concern for others on the basis of our shared common humanity.

1. Recognition of equal worth and dignity. Leaders need to make sure that they exercise active recognition in all relational affairs and, that in all company's operations, as well in those of its suppliers, the recognition of each person's equal worth and dignity is not only assured, but also actively promoted.

2. Active agency and care. Active agency connotes the capacity of a leader "to reason selfconsciously, to be self-reflective and to be self-determining. It bestows both opportunities and duties..." (Held, 2005, p. 12) - opportunities to act (or not) and ensure responsible behavior, and duties to ensure that leaders or company action "does not curtail and infringe on the life chances and opportunities of others" (ibid., p. 13). Moreover, leaders need to demonstrate a caring attitude toward others, matters of ethics and justice, and the world's most pressing problems.

3. Personal responsibility and accountability. Leaders make choices, live and promote certain values and have both the potential and capabilities to do good. Thus, they need to be aware of themselves, their values and responsibilities, make conscious choices and be accountable for the (ir-)responsible behavior of their organizations at all times and in all places. As leading actors in a globalized world they do not need to have higher moral standards than others, but given the scope of their responsibilities and the fact that the price of their ethical failure is greater, they ought to act consciously, carefully, and responsibly (Ciu1la, 2006; Price, 2005) at home and abroad.

4. Stakeholder engagement and dialogue. Leadership in a global stakeholder society is a partnership effort to contribute to a sustainable future. Responsible global leaders engage themselves among equals, make sure that all stakeholders are recognized, that their concerns are heard and appreciated and that a participative stakeholder dialogue is employed to ensure an inclusive approach to cosmopolitan problem-solving.

5. Deliberation on matters of global fairness and justice. Connected to the fourth principle, the principle of deliberation recognizes that in a complex and connected world leadership decisions cannot be made in isolation but need to be informed by, and ultimately legitimated by, a process of deliberation of leaders and stakeholders, in particular regarding matters of the cosmopolitan moral universe. Thus, in matters of global fairness, justice and assistance, moral and political deliberation processes of citizens of reason are of utmost importance.

6. Inclusiveness and subsidiarity. In line with principles 4 and 5 the sixth principle emphasizes the importance of inclusive behavior and decision making. Matters of normative significance have to be dealt with in an inclusive manner, including and considering all whom 
the issues at hand may concern. In addition, a leader should actively support and nurture leadership "on the ground" to enable others to lead and act responsibly. Given its complexity, responsible leadership on a global scale is shared leadership. It therefore becomes a crucial task for leaders to grow and develop leadership capabilities among her constituencies.

7. Assistance in creating a decent life world and building human capabilities. We have argued that corporations and their leaders as part of the cosmopolitan commonwealth have the capabilities to act as agents and thus proponents of justice in the countries in which they operate. As cosmopolitan citizens they bear a co-responsibility in promoting human and social rights. In addition, they need to assist people in urgent need and to be active supporters of decent living conditions in the countries in which they operate. Finally, they should assist in building human capabilities (Nussbaum and Sen, 1993), e.g., by initiating and supporting both basic and professional education. Fostering human capabilities is arguably the best way to help people to help themselves - to become fully integrated, contributing and consuming members of the global business community. This principle does not mean that corporations should transform themselves into social agencies; rather, as outlined above, it connotes the cosmopolitan expectation that the powerful and privileged have a specific responsibility to address urgent needs, to foster human capabilities and ultimately to serve others (Greenleaf, 1977/2002).

8. Sustainability and stewardship. Finally, the eighth principle connotes the leader's co-responsibility in contributing to a sustainable future. It specifies that all corporate and thus economic activity must be consistent with the stewardship of our planet's natural resources and the cosmopolitan right of future generations to lead a decent life. Leaders should consider themselves not only citizens of the world, but also stewards of values and resources on this planet (Maak and Pless, 2006b). Thus, they need to make sure that their and their company's decisions and actions are contributing to a better, i.e., more sustainable world, and are not endangering it.

These leadership principles demonstrate that the cosmopolitan vision is best served by a multi-layered cosmopolitan perspective, a mix of regulative principles, interpretative activity (Held, 2005, p. 18), and mediating efforts to reconcile fundamental, basic moral, and political principles with an increasingly complex global business practice. Obviously, these principles are rooted in and reflect specific norms and values about how we ought to live together on this planet, what we owe each other as human beings (Scanlon, 1998), and what people in privileged positions shall contribute to make the cosmopolitan universe as inclusive, just and life-conducive as possible.

\section{Conclusion: toward cosmopolitan business ethics}

In this article, we have argued that business leaders should consider themselves as cosmopolitan citizens and "agents of world benefit". Business leaders are key actors and agents in establishing a global economy with a human face by contributing to a cosmopolitan business practice in a world, "where a host of complex relationships link people across national borders, and the accident of birth in any given nation now looks in some ways as morally arbitrary as the accidents of race, class, and sex. We need to devote ourselves to working out new theories that will prove more fully adequate to this world" (Nussbaum, 2004, p. 171). Our effort to present some key features of a cosmopolitan business ethic attempts to contribute to a better understanding of the responsibilities of business leaders in such a connected world. Ultimately, cosmopolitanism "is not so much a matter of having exact rules about how precisely we ought to behave, as of recognizing the relevance of our shared humanity in making the choices we face" (Sen, 1999, p. 283).

Whether or not, as Beck (2008) argues, "cosmopolitan corporations" or maybe even a "cosmopolitan capitalism" are in the making still remains to be seen. There is certainly enough reason to believe that the success of the twenty-first century cosmopolitan project depends on active participation of business 
leaders around the world. This project has often been called utopian; yet, it is a "realistic utopia" (Rawls, 1999, p. 127) as we witness, for better and for worse as the recent financial crisis has shown, an historically unique level of connectedness on this planet. With it comes the equally unique potential for those in powerful and privileged positions to contribute in profound ways to the betterment of the world, unleashing human flourishing and thus true "shared value", that is, the value of our shared humanity. Or, as Nobel laureate Muhammad Yunus puts is, "we create what we want... what we want and how we get to it depends on our mindsets" (2007, p. 246) - as business leaders and citizens of the world.

\section{References}

Adler, N. J.: 2006, 'The Arts \& Leadership: Now that we can do Anything, What will we do?', Academy of Management Learning \& Education 5(4), 486-499.

Appiah, K. A.: 2006, Cosmopolitanism. Ethics in a World of Strangers (W.W. Norton \& Company, New York and London).

BAWB (Business as an Agent of World Benefit): 2006, First Conference on 'Business as an Agent of World Benefit', Held by Case Western Reserve University (Academy of Management \& UN Global Compact, Cleveland, OH).

Beck, U.: 2008, 'Reframing Power in the Globalized World', Organization Studies 29(5), 793-804.

Beetham, D.: 1998, 'Human Rights as a Model for Cosmopolitan Democracy', in D. Archibugi, D. Held and M. Köhler (eds.), Re-imagining Political Community (Polity Press, Cambridge), pp. 58-71.

Benhabib, S.: 2006, Another Cosmopolitanism (Oxford University Press, Oxford/New York).

Bennis, W. and B. Nanus: 1985, Leaders: The Strategies for Taking Charge (Harper \& Row, New York).

Bohman, J. and M. Lutz-Bachmann (eds.): 1997, Perpetual Peace: Essays on Kant's Cosmopolitan Ideal (MIT Press, Boston).

Brock, G. and H. Brighouse (eds.): 2005, The Political Philosophy of Cosmopolitanism (Cambridge University Press, Cambridge).

Burns, J. M.: 1978, Leadership (Perennial, New York).

Chatterjee, D. K. (ed.): 2004, The Ethics of Assistance: Morality and the Distant Needy (Cambridge University Press, Cambridge).

Cheah, P.: 2006, Inhuman Conditions: On Cosmopolitanism and Human Rights (Harvard University Press, Cambridge, MA/London).
Ciulla, J. (ed.): 1998, Ethics, the Heart of Leadership (Praeger, Westport, CT, London).

Ciulla, J.: 2006, 'Ethics, the Heart of Leadership', in Th. Maak and N. M. Pless (eds.), Responsible Leadership (Routledge, London/New York), pp. 17-32.

Crosby, B. C. and J. M. Bryson: 2005, Leadership for the Common Good: Tackling Public Problems in a SharedPower World, 2nd Edition (Jossey-Bass, San Francisco, CA).

Dallmayr, F.: 2003, 'Cosmopolitanism. Moral and Political', Political Theory 31(3), 421-442.

Delanty, G.: 2006, 'The Cosmopolitan Imagination: Critical Cosmopolitanism and Social Theory', The British Journal of Sociology 57(1), 25-47.

Donaldson, T. and L. E. Preston: 1995, 'The Stakeholder Theory of the Corporation: Concepts, Evidence, and Implications', Academy of Management Review 20(1), 65-91.

Driver, J.: 2007, 'Cosmopolitan Virtue', Social Theory and Practice 33(4), 595-608.

Elkington, J.: 1998, Cannibals with Forks: The Triple Bottom Line of $21^{\text {st }}$ Century Business (New Society Publishers, Gabriola Island, BC/Stony Creek, CT).

Frankfurt, H. G.: 1988, The Importance of What we Care About (Cambridge University Press, Cambridge/ New York, NY).

Freeman, R. E.: 1984, Strategic Management: A Stakeholder Approach (Pitman Publishers, Boston).

Freeman, R. E.: 1994, 'The Politics of Stakeholder Theory: Some Future Directions', Business Ethics Quarterly 4(4), 409-422.

Freeman, R. E., K. Martin, B. Parmar, M. Cording and P. H. Werhane: 2006, 'Leading Through Values and Ethical Principles', in R. J. Burke and C. L. Cooper (eds.), Inspiring Leaders (Routledge, London/ New York), pp. 149-174.

Friedman, T. L.: 2005, The World is Flat (Farrar, Strauss and Giroux, New York).

Gilligan, C.: 1982, In a Different Voice (Harvard University Press, Cambridge, MA).

Greenleaf, R. K.: 1977/2002, Servant Leadership. A Journey into the Nature of Legitimate Power \& Greatness, 25th Anniversary Edition (Paulist Press, New York/ Mahwah, NJ).

Held, D.: 1995, Democracy and the Global Order: From the Modern State to Cosmopolitan Governance (Polity Press, Cambridge).

Held, D.: 2005, 'Principles of Cosmopolitan Order', in G. Brock and H. Brighouse (eds.), The Political Philosophy of Cosmopolitanism (Cambridge University Press, Cambridge), pp. 10-27.

Held, V.: 2005, Ethics of Care (Oxford University Press, New York/Oxford). 
Hooijberg, R., J. G. Hunt and G. E. Dodge: 1997, 'Leadership Complexity and Development of the Leaderplex Model', Journal of Management 23, 375408.

Jones, T. M., W. Felps and G. Bigley: 2007, 'Ethical Theory and Stakeholder-Related Decisions: The Role of Stakeholder Culture', Academy of Management Review 32(1), 137-155.

Kant, I.: 1795, 'Perpetual Peace: A Philosophical Sketch', in H. Reiss (ed.), Kant: Political Writings (Cambridge University Press, Cambridge, 1994), pp. 93-131.

Küng, H.: 1991, Global Responsibility: In Search for a New World Ethic (Crossroad, New York).

Küng, H. and K.-J. Kuschel: 1995, A Global Ethic: The Declaration of the Parliament of the World's Religions (Continuum, New York).

Kuper, A. (ed.): 2005, Global Responsibilities. Who Must Deliver on Human Rights? (Routledge, New York/ London).

Kymlicka, W. (ed.): 1995, The Rights of Minority Cultures (Oxford University Press, Oxford).

Levy, O., S. Beechler, S. Taylor and N. A. Boyacigiller: 2007, 'What we Talk About When we Talk About 'Global Mindset': Managerial Cognition in Multinational Corporations', Journal of International Business Studies 38, 231-258.

Lodge, G. and C. Wilson: 2006, A Corporate Solution to Poverty (Princeton University Press, Princeton/ Oxford).

Lord, R. G. and D. J. Brown: 2001, 'Leadership, Values, and Subordinate Self-Concepts', The Leadership Quarterly 12, 133-152.

Maak, Th.: 2007, 'Responsible Leadership, Stakeholder Engagement and the Emergence of Social Capital', Journal of Business Ethics 74(4), 329-343.

Maak, Th. and N. M. Pless: 2006a, 'Responsible Leadership: A Relational Approach', in Th. Maak and N. M. Pless (eds.), Responsible Leadership (Routledge, London/New York)), pp. 33-53.

Maak, Th. and N. M. Pless: 2006b, 'Responsible Leadership in a Stakeholder Society', Journal of Business Ethics 66, 99-115.

Maak, Th. and N. M. Pless: 2008, 'Responsible Leadership in a Globalized World: A Cosmopolitan Perspective', in G. Palazzo and A. G Scherer (eds.), Handbook of Global Corporate Citizenship (Edward Elgar, Cheltenham), pp. 430-453.

Maccoby, M.: 2007, The Leaders we Need and What Makes us Follow (Harvard Business School Press, Boston, $\mathrm{MA})$.

May, L.: 1993, Sharing Responsibility (Chicago University Press, Chicago).
Miller, D.: 2005, 'Distributing Responsibilities', in A. Kuper (ed.), Global Responsibilities. Who Must Deliver on Human Rights? (Routledge, New York/ London), pp. 95-115.

Mitchell, R. K., B. R. Agle and D. J. Wood: 1997, 'Toward a Theory of Stakeholder Identification and Salience: Defining the Principle of who and What Really Counts', Academy of Management Review 22(4), 853-886.

Nagel, Th.: 1991, Equality and Partiality (Oxford University Press, New York).

Noddings, N.: 2003, Caring: A Feminine Approach to Ethics and Moral Education, 2nd Rev. Edition (University of California Press, Berkeley).

Nussbaum, M. C.: 1996, 'Patriotism and Cosmopolitanism', in J. Cohen (ed.), For Love of Country: Debating the Limits of Cosmopolitanism (Beacon Press, Boston, MA), pp. 3-17.

Nussbaum, M. C.: 2004, 'Women and Theories of Global Justice: Our Need for New Paradigms', in D. K. Chatterjee (ed.), The Ethics of Assistance: Morality and the Distant Needy (Cambridge University Press, Cambridge), pp. 147-176.

Nussbaum, M. C.: 2005, 'Beyond the Social Contract: Capabilities and Global Justice', in G. Brock and H. Brighouse (eds.), The Political Philosophy of Cosmopolitanism (Cambridge University Press, Cambridge), pp. 196-228.

Nussbaum, M. C. and A. Sen (eds.): 1993, The Quality of Life (Clarendon Press, Oxford).

O’Neill, O.: 2004, 'Global Justice: Whose Obligations', in D. K. Chatterjee (ed.), The Ethics of Assistance: Morality and the Distant Needy (Cambridge University Press, Cambridge), pp. 242-259.

O’Neill, O.: 2005, 'Agents of Justice', in A. Kuper (ed.), Global Responsibilities. Who Must Deliver on Human Rights? (Routledge, New York/London), pp. 37-52.

Pless, N. M.: 2007, 'Understanding Responsible Leadership: Roles Identity and Motivational Drivers. The Case of Dame Anita Roddick', Journal of Business Ethics 74(4), 437-456.

Pless, N. M. and Th. Maak: 2005, 'Relational Intelligence for Leading Responsibly in a Connected World', in K. M. Weaver (ed.), Proceedings of the 65th Annual Meeting of the Academy of Management (AOM, Honolulu, HI).

Pogge, Th.: 2002, World Poverty and Human Rights (Polity Press, Cambridge/Malden, MA).

Pogge, Th.: 2005, 'A Cosmopolitan Perspective on the Global Economic Order', in G. Brock and H. Brighouse (eds.), The Political Philosophy of Cosmopolitanism (Cambridge University Press, Cambridge), pp. 92-109. 
Pogge, Th. (ed.): 2007, Freedom from Poverty as a Human Right? (Oxford University Press, Oxford).

Porter, M. E. and M. R. Kramer: 2006, 'Strategy \& Society. The Link Between Competitive Advantage and Corporate Social Responsibility', Harvard Business Review December, 78-92.

Post, J. E., L. E. Preston and S. Sachs: 2002, Redefining the Corporation: Stakeholder Management and Organizational Wealth (Stanford University Press, Stanford, CA).

Prahalad, C. K.: 2005, The Fortune at the Bottom of the Pyramid: Eradicating Poverty through Profits (Wharton School Publishing, Upper Saddle River, NJ).

Price, T. L.: 2005, Understanding Ethical Failures in Leadership (Cambridge University Press, New York).

Rawls, J.: 1999, The Law of Peoples (Harvard University Press, Cambridge, MA/London).

Rost, J. C.: 1991, Leadership for the 21 $1^{\text {st }}$ Century (Quorum, Westport, CT/London).

Sachs, J.: 2008, Common Wealth. Economics for a Crowded Planet (Allen Lane, London).

Scanlon, T. M.: 1998, What we Owe to Each Other (The Belknap Press at Harvard University Press, Cambridge, MA/London).

Schneider, M.: 2002, 'The Stakeholder Model of Organizational Leadership', Organization Science 13(2), 209220.
Sen, A.: 1999, Development as Freedom (Oxford University Press, Oxford/New York).

Smith, A.: 1759, The Theory of Moral Sentiments, Glasgow Edition (Liberty Fund, Indianapolis, IN).

Vertovec, S. and R. Cohen (eds.): 2002, Conceiving Cosmopolitanism: Theory, Context, and Practice (Oxford University Press, Oxford/New York).

Walzer, M.: 1994, Thick and Thin: Moral Argument at Home and Abroad (University of Notre Dame Press, Notre Dame, IN).

Wheeler, D. and M. Sillanpäa: 1997, The Stakeholder Corporation (Pitman Publishing, London).

Young, I. M.: 2004, 'Responsibility and Global Justice', Journal of Political Philosophy 12(4), 365-388.

Yunus, M.: 2007, Creating a World without Poverty (Public Affairs, New York).

Thomas Maak University of St. Gallen, Guisanstrasse 11, 9010 St. Gallen, Switzerland E-mail: thomas.maak@unisg.ch

Nicola M. Pless

ESADE Business School, Av. Pedralbes 60-62, 08034 Barcelona, Spain E-mail:nicola.pless@esade.edu 